\title{
MASKNE: Mask-InducedAcneFlare During Coronavirus Disease-19. What is it and How to Manage it?
}

\author{
Laura Pauline Kosasih \\ Department of Dermatology, Cardiff University, Cardiff, Wales, United Kingdom
}

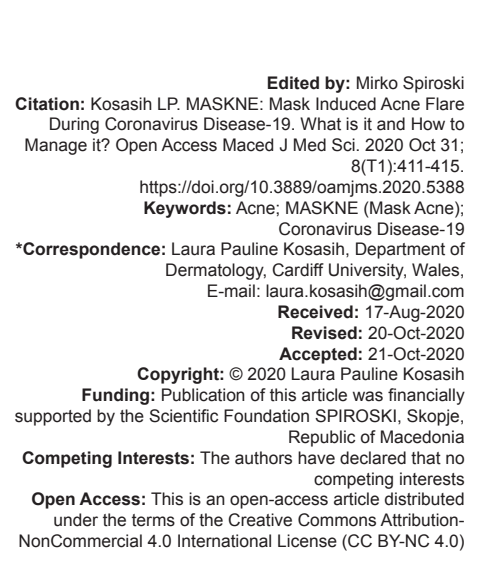

Introduction

Coronavirus disease (COVID)-19 is a disease caused by SARS-CoV-2. It was first discovered in late December 2019, in Wuhan, China [1]. The World Health Organization (WHO) later declared in as a pandemic due to its rapid spreading [2]. The outbreak of COVID-19 has affected many facets of life globally, including personal habits and lifestyle. It is implored by the Center for Disease Control and Prevention and WHO for people to take preventive measures in mitigating the spread, including covering mouth and nose with a mask when around others [3], [4]. This new arrangement has a distinct impact on daily life. Individuals are wearing masks more often and longer than before, especially health workers who are working at a higher risk of transmission environment. Thus, it leads to a local acne outbreak in the area covered by the mask, which is popularly called as "maskne or mask acne." This phenomenon is supported by accumulating data about adverse effects on the skin against personal protective equipment (PPE), including mask. A study discovered that $59.6 \%$ of individuals wearing mask regularly have experienced acne outbreak [5]. This finding is supported by several literature resources highlighting this phenomenon [6], [7], [8].

Many have agreed that acne may affect many aspects of an individual's life. A study asserts that acne impacts greatly in one's psychological state; persons with acne are often at greater risk of lowered quality of life [9]. A cohort study also shows that adolescents and adults suffering from acne have higher rates of anxiety, low self-esteem, and depression compared to individuals without acne [10]. Therefore, this rising undesirable phenomenon should be addressed and mitigated properly since the pandemic is still continuing to allow individuals to have a decent quality of life.

\section{COVID-19}

\section{A brief review}

SARS-CoV-2 is a $\beta$-coronavirus (CoV), which primarily targets the respiratory tract [11]. It is an enveloped virus with a single positive-sense stranded RNA genome [12]. The CoV has 4 genera $(\alpha, \beta, \delta$, and $\gamma$ ). However, it is identified that only $\alpha$ and $\beta$ can infect mammals, while $\delta$ and $\gamma$ can infect birds [13]. The origin of SARS-CoV-2 has remained elusive, but it is found that its genome sequence is identical to a bat CoV RaTG13 (96.2\%), while it is also shared $79.5 \%$ similarity to SARS-CoV-2. Thus, it is postulated that the natural host of the originate virus is bat, with an unknown intermediate host [13]. 


\section{Route of Transmission}

Due to its nature, it is believed that personto-person transmission is plausible through inhaled respiratory microdroplets spread by coughing or sneezing from an infected person or carrier [14]. However, the exact route of transmission is still elusive. Several findings show that it may also be transmitted through the mucous membrane of the eyes, and it is also proposed that transmission through gastrointestinal tract is plausible [14], [15], [16].

The understanding of the basic reproduction number is imperative in managing the transmissibility. The R nought (R0) can be defined as the ability of the pathogen to produce a secondary infection through an infected person. The R0 of SARS-CoV 2 is estimated in a range of 1.46-6.49, with a mean of 3.28 [17], which means that COVID-19 is considered contagious.

\section{Pathogenesis}

It is discovered that angiotensin-converting enzyme 2, which can be found in the lower respiratory tract, acts as a receptor for SARS-CoV-2. The envelope spike $S$ glycoprotein will bind and initiates membrane fusion into the host cell [12], [13]. After successfully fused, the viral genome RNA is then released into the cytoplasm, and the uncoated RNA encodes nonstructural protein to form a replication-transcription complex (RCT). The RCT then synthesis a new set of subgenomic RNA which plays a major role in encoding the necessary accessory and structural proteins to form a new virus [12]. When the virus enters the cells, its antigen will be presented to the antigen presentation cell of the host. This event will induce the immune response of the body.

\section{Clinical Manifestation}

The clinical characteristic of COVID-19 varies from mild-to-severe. The main symptoms are usually fever $(98 \%)$, dry cough $(76 \%)$, myalgia, or fatigue (44\%) [18]. Other less common manifestations include nasal congestion, headache, runny, nose, sore throat, vomiting, and diarrhea. In severe condition, hypoxemia and dyspnea are often found, leading to acute respiratory distress, difficult-to-manage metabolic acidosis, and coagulation, which may lead to fatality [14], [18], [19]. It is noteworthy that some individuals may spread the virus while being asymptomatic. Therefore, it is essential to follow the recommended preventive measures such as practicing hand hygiene, wearing a mask, and limiting social gatherings [3].

\section{Acne}

\section{Pathogenesis}

Acne is a multifactorial pilosebaceous inflammatory disease. It is very common and most often seen in adolescents [20], [21]. Even though the exact pathogenesis of acne has not been fully elucidated, there are four essential facets that have been widely adopted in its pathogenesis. First is the hyperproliferation of follicular epithelial cells, leading to follicular plugging, excess sebum, inflammation, and the role of Propionibacterium acne or recently is called as Cutibacterium acnes (C. acnes) [20], [22], [23], [24].

Hormones and immune responses are believed to have a distinct role in each phase.

Initially, the infundibulum part of a hair follicle is packed with an abundant number of keratinous cells and highly cohesive keratinocytes resulting in microcomedone. It is believed that the formation of microcomedone is also influenced by the decreased level of linoleic acid and increased $C$. acnes metabolism [23], [24]. It is also proposed that an elevated level of androgen and increased activity of interleukin 1 plays a role in the overproduction of the sebum [22], [23]. When the excess sebum is trapped in the follicle with the keratinous squamae, a thin wall cystic lesion (comedone) is formed. The overgrowth of $C$. acnes and excess sebum as its nutrient emulates a bigger formation of the previous lesion (papule or nodule). Finally, the mixture of keratin, hair, and sebum provokes a non-immune foreign body inflammation process [23], [24].

\section{Acne and Mask}

During this pandemic, one of many means of mitigating the spread of the virus is wearing a mask. In June 2020, the WHO also updated its guidance, stating that individuals and healthcare workers should wear a mask in appropriate settings and environments [2]. This guidance leads to a fact that many people wearing mask in a longer period. Acne flare due to prolonged mask-wearing has been reported lately in both general and healthcare populations. Several case reports and literature have been addressed to discuss and manage the undesirable effects of the prolong-use of PPE, including mask-related acne outbreak [5], [7], [8], [25].

The lesions are mostly found in the local area covered by the mask, and the severity varies 
from mild-to-severe in each literature [6], [7], [8]. It is proposed that the possible factor of this particular localized outbreak is the increased humidity and temperature in the covered area. It is known that high temperature can affect the rate of sebum secretion. It is also postulated that increased humidity might increase the amount of squalene in the skin [26]. In addition, studies have discovered that increased humidity and excess sweating lead to swelling of the epidermal keratinocytes [27]. All these alterations lead to acute obstruction and acne aggravation [26] (Figure 1).

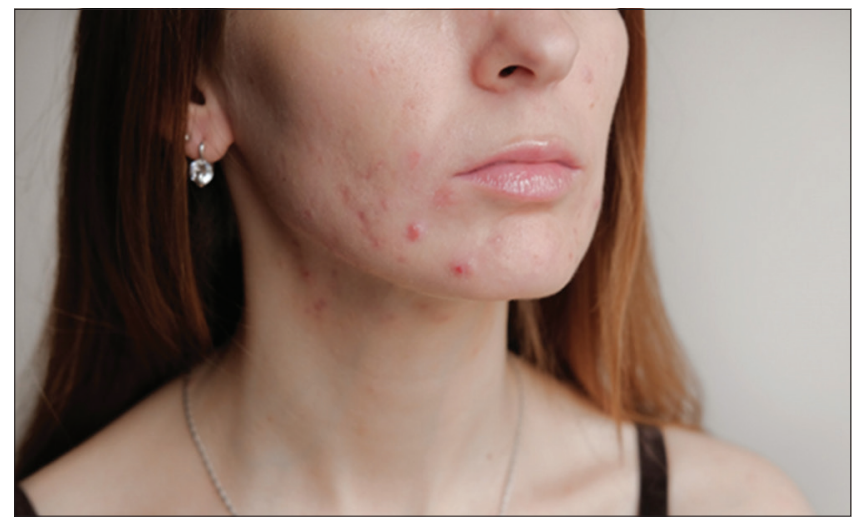

Figure 1: MASKNE. Adapted from https://www.marketwatch.com/ story/maskne-yes-mask-acne-is-now-a-thing-2020-06-26

These hypotheses are also supported by a case study of tropical acne. It is known that hot and humid environment has a significant correlation with acne flares [28]. However, it is concluded that the exact pathogenesis of acne flare due to mask-wearing remains a puzzle.

It is noteworthy that not only may prolonged mask-wearing affect acne outbreak but it also might increase the temptation of touching the face due to annoying acne or itch, which may increase the risk of COVID-19 transmission through the respiratory tract [29].

\section{Recommendation and Prevention}

The duration of this pandemic is still uncertain, with a probability of an upcoming of second wave in most continents. Thus, suggestions and recommendations in enduring the effects of long-term mask-wearing are crucial for the sake of the health and comfort of each individual, especially for healthcare workers, who need to wear both regular and medical masks most of the time.

There are several preventive measures that might be implemented. Frequent break time of wearing mask is highly recommended to shorten the duration and exposure of the mask [30]. It is also recommended to replace the surgical mask and N95 mask routinely. Han et al. [7] suggest that mask should be replaced after $4 \mathrm{~h}$ for surgical mask and 3 days for N95 mask, while Desai et al. [31] recommend to take a 15-min break after $2 \mathrm{~h}$ of wearing mask. Preventative measures such as applying oil-controlling moisturizer (i.e., with licochalcone $A$ as one of the ingredients) or dressing application before wearing a mask is also suggested to decrease sebum secretion [7], [32], [33]. However, it is also implored to always reassure that those vehicles do not interfere with the mask seal, allowing less protection against the virus. A literature source also asserts the importance of an improved mask design focused on safety, comfort, and tolerability [34]. American Academy of Dermatology Association also suggests avoiding new skincare that might irritate skin or increase the use of strong products such as retinoid, chemical peeling agents, and exfoliant [35].

Another literature source also suggests a general approach to control the acne outbreak. First is to wash the face twice daily with warm water and opt for an appropriate cleanser; a strong alkaline soap is not recommended. A study also stresses the importance to do this routine before wearing the mask [31]. Second, it is advisable to wear no cosmetic or light cosmetic only. Finally, mild lesions can be treated with topical antibiotic or retinoid, while severe condition might be treated with systemic minocycline or isotretinoin [36].

Although there are some inevitable adverse effects in the prolonged use of mask, wearing mask properly is one of many essential approaches in protecting ourselves and others. The abovementioned suggestions aim to hinder and alleviate the undesirable effects and maintain compliance.

\section{Limitation and Conclusion}

There are some limitations of this review, including the lack of robust data and variation of the duration of wearing the mask. Due to the complexity of acne pathogenesis, there are some gaps in the literature sources that have been reviewed since most of the sources do not consider other risk factors, such as body mass index, skin type, and hormonal imbalance. In addition, further information about the material of the mask has not been included yet in most literature, this may contribute to a mistaken diagnosis of contact dermatitis eruption. Most of the literature reviews published are either case reports or clinical reviews. Thus, a thorough study is needed to elucidate and manage this issue. To conclude, in this era of the pandemic, assuring the safety of ourselves and others by wearing proper PPE is of paramount importance. However, occupationally induced skin condition (in this case, due to PPE) cannot be neglected and must be minimalized. 


\section{References}

1. Du Toit A. Outbreak of a novel coronavirus. Nat Rev Microbiol. 2020;18(3):123.

PMid:31988490

2. World Health Organization. Timeline of WHO's response to COVID-19. World Health Organ. 2020;(1):1-27.

3. World Health Organisation. COVID-19 Transmission and Protective Measures. Geneva: World Health Organisation; 2020. Available from: https://www.who.int/westernpacific/ emergencies/covid-19/information/transmission-protectivemeasures. [Last accessed on 2020 Aug 16].

4. Centers for Disease Control and Prevention. How to Protect Yourself and Others. Coronavirus Disease; 2019. Available from: https://www.cdc.gov/coronavirus/2019-ncov/preventgetting-sick/prevention.html. [Last accessed on 2020 Aug 16].

5. Foo CC, Goon AT, Leow YH, Goh CL. Adverse skin reactions to personal protective equipment against severe acute respiratory syndrome a descriptive study in Singapore. Contact Dermatitis. 2006;55(5):291-4. https://doi. org/10.1111/j.1600-0536.2006.00953.x

PMid:17026695

6. Tan KT, Greaves MW. N95Acne. IntJDermatol. 2004;43(7):522-3. PMid:15230894

7. Han C, Shi J, Chen Y, Zhang Z. Increased flare of acne caused by long-time mask wearing during COVID-19 pandemic among general population. Dermatol Ther. 2020;(1):e13704. https://doi. org/10.1111/dth.13704

\section{PMid:32472634}

8. Elisheva R. Adverse effects of prolonged mask use among healthcare professionals during COVID-19. J InfectDis Epidemiol. 2020;6(3):19810. https://doi.org/10.23937/2474-3658/1510130

9. Zaenglein AL. Acne vulgaris. $N$ Engl $J$ Med. 2018;379(14):1343-52.

PMid:30281982

10. Ramrakha S, Fergusson DM, Horwood LJ, Dalgard F, Ambler A, Kokaua J, et al. Cumulative mental health consequences of acne: 23-year follow-up in a general population birth cohort study. Br J Dermatol 2016;175:1079-81. https://doi.org/10.1111/ bjd. 13786

PMid:25819106

11. Rothan HA, Byrareddy SN. The epidemiology and pathogenesis of coronavirus disease (COVID-19) outbreak. J Autoimmun. 2020;109:102433. https://doi.org/10.1016/j.jaut.2020.102433 PMid:32113704

12. Li X, Geng M, Peng Y, Meng L, Lu S. Molecular immune pathogenesis and diagnosis of COVID-19. J Pharm Anal. 2020;10(2):102-8.

PMid:32282863

13. Guo YR, Cao QD, Hong ZS, Tan YY, Chen SD, Jin HJ, et al. The origin, transmission and clinical therapies on coronavirus disease 2019 (COVID-19) outbreak an update on the status. Mil Med Res. 2020;7(1):11. https://doi.org/10.1186/s40779-020-00240-0

14. Li H, Liu SM, Yu XH, Tang SL, Tang CK. Coronavirus disease 2019 (COVID-19): Current status and future perspectives. Int J Antimicrob Agents. 2020;55(5):105951. https://doi. org/10.1016/.ijantimicag.2020.105951

PMid:32234466

15. Wei LC, Fen LX, Fang JZ. 2019-nCoV transmission through the ocularsurfacemustnotbeignored. Lancet.2020;395(10224):e39. https://doi.org/10.1016/s0140-6736(20)30313-5 PMid:32035510

16. Setti L, Passarini F, De Gennaro G, Barbieri P, Perrone MG,
Borelli M, et al. Airborne transmission route of covid-19: Why 2 meters $/ 6$ feet of inter-personal distance could not be enough. Int J Environ Res Public Health. 2020;17(8):2932. https://doi. org/10.3390/ijerph17082932

PMid:32340347

17. Liu Y, Gayle AA, Wilder-Smith A, Rocklöv J. The reproductive number of COVID-19 is higher compared to SARS coronavirus. J Travel Med. 2020;27(2):taaa021. https://doi.org/10.1093/jtm/ taaa021

\section{PMid:32052846}

18. Huang $\mathrm{C}$, Wang $\mathrm{Y}$, Li X, Ren L, Zhao J, Hu Y, et al. Clinical features of patients infected with 2019 novel coronavirus in Wuhan, China. Lancet 2020;395(10223):497-506. https://doi. org/10.1016/s0140-6736(20)30183-5

19. Chen N, Zhou M, Dong X, Qu J, Gong F, Han Y, et al. Epidemiological and clinical characteristics of 99 cases of 2019 novel coronavirus pneumonia in Wuhan, China: A descriptive study. Lancet. 2020;395(10223):507-13. https://doi.org/10.1016/ s0140-6736(20)30211-7

PMid:32007143

20. Collier CN, Harper JC, Cantrell WC, Wang W, Foster KW, Elewski BE. The prevalence of acne in adults 20 years and older. J Am Acad Dermatol. 2008;58(1):56-9. https://doi.org/10.1016/j. jaad.2007.06.045

PMid: 17945383

21. Dursun R, Daye M, Durmaz K. Acne and rosacea: What's new for treatment? Dermatol Ther. 2019;32(5):e13020. https://doi. org/10.1111/dth. 13020

PMid:31294907

22. Harper JC. An update on the pathogenesis and management of acne vulgaris. J Am Acad Dermatol. 2004;51(Suppl 1):S36-8. PMid:15243503

23. Goldsmith LA, Katz SI, Gilchrest BA, Paller AS, Leffell DJ, Wolff K. Fitzpatrick's Dermatology in General Medicine. $8^{\text {th }}$ ed. New York: McGraw-Hill; 2012. p. 165-7. https://doi. org/10.1111/j.1524-4725.2008.34211.x

24. Toyoda M, Morohashi M. Pathogenesis of acne. Med Electron Microsc. 2001;34(1):29-40.

PMid:11479771

25. Zuo Y, Hua W, Luo Y, Li L. Skin reactions of N95 masks and medial masks among health-care personnel: A selfreport questionnaire survey in China. Contact Dermatitis. 2020;83(2):145-7. https://doi.org/10.1111/cod.13555 PMid:32297349

26. Narang I, Sardana K, Bajpai R, Garg VK. Seasonal aggravation of acne in summers and the effect of temperature and humidity in a study in a tropical setting. J Cosmet Dermatol. 2019;18(4):1098-104. https://doi.org/10.1111/jocd.12777 PMid:30238598

27. Sardana K, Sharma RC, Sarkar R. Seasonal variation in acne vulgaris myth or reality. J Dermatol. 2002;29(8):484-8. https:// doi.org/10.1111/j.1346-8138.2002.tb00313.x

PMid: 12227481

28. Wells JM. Tropical acne--one hundred cases. J R Army Med Corps. 1981;127(1):55-8.

PMid:6453225

29. Gupta MK, Lipner SR. Personal protective equipment recommendations based on COVID-19 route of transmission. J Am Acad Dermatol 2020;83:e45-6. https://doi.org/10.1016/j. jaad.2020.04.068

PMid:32330629

30. Rebmann T, Carrico R, Wang J. Physiologic and other effects and compliance with long-term respirator use among medical intensive care unit nurses. Am J Infect Control. 
2013;41(12):1218-23. https://doi.org/10.1016/j.ajic.2013.02.017 PMid:23768438

31. Desai SR, Kovarik C, Brod B, James W, Fitzgerald ME, Preston A, et al. COVID-19 and personal protective equipment: Treatment and prevention of skin conditions related to the occupational use of personal protective equipment. J Am Acad Dermatol. 2020;83(2):675-7. https://doi.org/10.1016/j.jaad.2020.05.032 PMid:32416206

32. Darlenski R, Tsankov N. COVID-19 pandemic and the skin: What should dermatologists know? Clin Dermatol. 2020;(1):4-6. https://doi.org/10.1016/j.clindermatol.2020.03.012

33. Chularojanamontri L, Tuchinda $\mathrm{P}$, Kulthanan $\mathrm{K}$, Pongparit $\mathrm{K}$. Moisturizers for acne: What are their constituents? J Clin Aesthet Dermatol. 2014;7(5):36-44.

PMid:24847408
34. Johnson AT. Respirator masks protect health but impact performance: A review. J Biol Eng. 2016;10:4.

PMid:26865858

35. American Academy of Dermatology Association. 9 Ways to Prevent Face Mask Skin Problems. American Academy of Dermatology Association. Available from: https://www. aad.org/public/everyday-care/skin-care-secrets/face/ prevent-face-mask-skin-problems. https://doi.org/10.1016/j. jaad.2016.02.801. [Last accessed on 2020 Oct 20].

36. Long $\mathrm{H}$, Zhao H, Chen A, Yao Z, Cheng B, Lu Q. Protecting medical staff from skin injury/disease caused by personal protective equipment during epidemic period of COVID19: Experience from China. J Eur Acad Dermatol Venereol. 2020;34(5):919-21. https://doi.org/10.1111/jdv.16388

PMid:32441424 